\title{
Medical Telecommunication Systems Today: What has been Done -What can be Done
}

\section{Klaus Kayser*}

Institute of Pathology, Charite, Berlin, Germany

Background. Today's development of medical diagnostic and therapeutic tools is characterized by high speed, close connection and interaction with other scientific disciplines, by increasing differences of accessibility to the latest diagnostic and therapeutic research, by man's living conditions, and by locally high and low population densities. To notify, measure, and potentially smooth these differences, communication systems are mandatory that focus on distribution and practical access to improving individual patient's diagnosis and treatment as well as to monitor and assist in social health. In the following, development and implementation of medical telecommunication in the past, today, and expectations of its future characteristics are described.

Technology and public communication are the principal actors that force and steer application of communication technology in medicine. Communication is one principle prerequisite of life in man, and can be divided in active, passive, and inter-active applications [1,2]. Passive communication is a simple understanding of transferred signals by the receiver without potential changes of the receiver's parameters by the sender, in contrast to active communication that allows the receiver to alter the information at its source. Interactive communication permits both the sender and the receiver to modify the information and its transfer between both partners [3-5]. Characteristic examples are common television (passive), surgical or microscope remote control units (active), and teleconferencing or teleeducation (inter-active) $[6,7]$.

Telecommunication is based upon acoustic and visual signals that can separately be analyzed and transferred. Acoustic and visual communications have their individual specificities in terms of aims and human receiver actions. For example, acoustic information is limited to relatively short distances. In the ancient times it could only be stored by transfer into visual information (scripts) [8]. In medical diagnosis, transfer and spatial analysis of digitized visual information (computerized tomography, in vivo biopsies, stereotactic surgery, magnetic nuclear resonance, and others) have led to the greatest success in the last 30 years [3].

Obviously, the speed of practical implementation in natural sciences depends upon the public demands, such as war, leadership competition, or control of power. Surprisingly, the technology maturation of both acoustic (telephone, telegraph) and visual (television) communication lasted for about the same time, i.e., the earliest scientific experiments have been reported in 1837 and 1843 respectively [9]. Telephones have broadly got into use during and after the First World War, TV started its public implementation at the Olympic games in 1936 promoted by the Hitler regime. The strongest promotion, however, was the digitalization of signals and signal transfer. The development of chip technology led to high speed computers, digital cameras, and digitalization of speech. This means that all signals can be handled in the same manner, i.e. as a mathematical matrix, independently from their nature. This unique constellation reduces costs and opens the door to big markets.

Medical applications in the past started before the era of digitalization [10]. They are a derivative of mandatory astronaut's health control at their space missions, and were triggered by a severe car accident in a tunnel that connects the Boston airport with the
Massachusetts General Hospital [2]. Pathology, dermatology, and public health control were and still are the most frequently involved medical fields [11]. In contrast to the NASA's aim, most trials used medical telecommunication to bridge spatial distances in an active manner, such as intra-operative diagnosis (frozen section service) in the past. Eide and Nordrum in Tromsö, Norway performed routine intra-operative consultations using a specialized telepathology system, and gave the final proof that telemedicine is a useful technology to bridge differences in medical care between rural areas and a specialized medical university [12].

These are the following communication systems that were based upon fixed end users and could only communicate between these predefined vertices [7]. The scenario changed completely after the implementation of digitized telephone networks (ISDN, integrated services digital network), the appropriate communication standards, and the internet [5]. The consecutive result was an open access to applications of different nature which finally created the so called platforms and social forums. In medicine, the first and most successful specialized open access and source platform was implemented at the Institute of Pathology, University of Basels by Brauchli and Oberholzer, the so -called iPATH. Its open source allowed that it could be copied and implemented in several additional Universities [13]. It can be applied for various tasks, such as expert consultation in medicine (not only pathology), medical education and training, and for interactive teleconsultation too [13]. Two competition platforms have to be mentioned here, the UICC-TPCC (Union International Contre le Cancre TelePathology Consultation Center, Berlin) and that of the AFIP (Armed Forces Institute of Pathology, Washington, DC). Only commercialized iPATH survived until today, UICC-TPCC and AFIP closed due to financial reasons.

Today's medical applications are mainly bound to specific universities, and embedded in the field of diagnostic pathology $[14,15]$. Most of them serve for advertisement of specific applications, especially to make pathologist familiar with virtual slides (VS), which are digitized images acquired from the tissue of a whole glass slide [16]. The combination of telecommunication and VS technology would be an adequate system to provide frozen section services in rural areas. Such a VS network has been implemented in Eastern Quebeck, Canada by Tetu et al. [17] recently. In Canada too, similar systems have been installed for public health services such as monitoring elderly or patients at certain risks (heart infarction, brain insults, etc.) [18].

${ }^{*}$ Corresponding author: Klaus Kayser, Institute of Pathology, Charite, Berlin, Germany; E-mail: klaus.kayser@charite.de

Received January 17, 2012; Accepted January 23, 2012; Published January 26 2012

Citation: Kayser K (2012) Medical Telecommunication Systems Today: What has been Done -What can be Done. J Telecommun Syst Manage 1:e101. doi:10.4172/2167-0919.1000e101

Copyright: (๑) 2012 Kayser K. This is an open-access article distributed under the terms of the Creative Commons Attribution License, which permits unrestricted use, distribution, and reproduction in any medium, provided the original author and source are credited. 
Additional applications include open accessible hearing and visus tests, and specific remote surgery control systems such as the Galilleo system.

Telemedicine systems have also been successfully applied for continuous education in medicine as well as for teaching students [19]. Szymas reported a system that has been developed at the medical University in Poznan and that includes both the student's education and the related tests $[20,21]$.

Where to go? The technological development directs to mobile applications based upon satellite communication systems (LEO, low earth satellites), and standardized programs working in quite different operating systems (Windows, Unix, Android, etc.) and being composed of multiple applets [9]. A test version of such a system (MECES, medical electronic expert system) has been recently reported [9]. It includes the advantages of an open access forum such as Facebook, or Linkedin, and the logistics of Grid computing. MECES itself only provides the framework with attached server nodes. The servers perform specialized tasks that include image quality measurements, automated measurements and scoring of images acquired from immunohistochemically stained glass slides, and finally automated diagnosis support. It can be combined with information sets that are composed of VS and rare cases of educational value and which have been published in open access journals. The journal of Diagnostic Pathology (diagnosticpathology.org) publishes since one year articles including VS, which can be easily, embedded in related image libraries [22].

These systems fulfil the conditions of efficient telemedicine application in both developed and developing countries. They can remarkably reduce the increasing gap between locations with outstanding medical service and others, and do not require specific knowledge of handling [16]. They do require, however, a minimum of adequate environment and an increase of medical personnel, and long lasting financing.

\section{References}

1. Kayser K, Szymas J, Weinstein RS (2005) Telepathology and Telemedicine. Communication, Electronic Education and Publication in e-Health. Berlin Veterinärspiegel Verlag.

2. Weinstein RS, Graham AR, Richter LC, Bhattacharyya K, Yagi Y, et al. (2009) Overview of telepathology, virtual microscopy, and whole slide imaging: prospects for the future. Hum Pathol 40: 1057-1069.

3. Kayser K, Szymas J, Weinstein RS (1999) Telepathology: Telecommunication, Electronic Education and Publication in Pathology. Berlin, Heidelberg, New Yorck Springer.

4. Kayser K, Görtler J, Bogovac M, Bogovac A, Goldmann T, et al. (2009) Al (artificial intelligence) in histopathology--from image analysis to automated diagnosis. Folia Histochem Cytobiol 47: 355-361.

5. Kayser G, Kayser G, Görtler J, Kluge N, Wiech T, et al. (2010) Standards in virtual microscopy: from tissue processing to image acquisition and visualization. Diagnostic Pathology 5: 10.

6. Kayser K (2002) Interdisciplinary telecommunication and expert teleconsultation in diagnostic pathology: present status and future prospects. J Telemed Telecare 8: 325-330.

7. Görtler J, Berghoff M, Kayser G, Kayser K (2006) Grid technology in tissuebased diagnosis: fundamentals and potential developments. Diagn Pathol 1: 23.

8. Kayser K (1995) Telepathology in Europe. Its practical use. Arch Anat Cyto Pathol 43: 196-199.

9. Kayser K, Borkenfeld S, Djenouni A, Kayser G (2011) History and structures of telecommunication in pathology, focusing on open access platforms. Diagn Pathol 6: 110

10. Weinstein RS, Descour MR, Liang C, Bhattacharyya AK, Graham AR, et al. (2001) Telepathology overview: from concept to implementation. Hum Pathol 32: 1283-1299.

11. Kayser K, Beyer M, Blum S, Kayser G (2000) Recent developments and present status of telepathology. Anal Cell Pathol 21: 101-106.

12. Eide TJ, Nordrum I (1994) Current status of telepathology. APMIS 102: $881-$ 890.

13. Brauchli K, Oberholzer M (2005) The iPath telemedicine platform. J Telemed Telecare 2: 3-7.

14. Kayser K, Görtler J, Borkenfeld S, Kayser G (2011) Grid computing in image analysis. Diagn Pathol 1: 12.

15. Kayser K, Görtler J, Borkenfeld S, Kayser G (2011) How to measure diagnosisassociated information in virtual slides. Diagn Pathol 1: 9.

16. Kayser K, Borkenfeld S, Kayser G (2012) How to introduce virtual microscopy (VM) in routine diagnostic pathology: Constraints, ideas, and solutions. Anal Cell Pathol (Amst) 35: 3-10.

17. Têtu B, Fortin JP, Gagnon MP, Louahlia S (2011) The challenges of implementing a "patient-oriented" telepathology network; the Eastern Quebec telepathology project experience. Anal Cell Pathol (Amst) 35: 11-8.

18. Kayser K, Molnar B, Weinstein RS (2006) Virtual Microscopy-Fundamentals Applications Perspectives of Electronic Tissue - based Diagnosis. Berlin VSV Interdisciplinary Medical Publishing.

19. Szymas J, Lundin M (2011) Five years of experience teaching pathology to dental students using the WebMicroscope. Diagn Pathol 1: 13.

20. Szymas J (2000) Teleeducation and telepathology for open and distance education. Anal Cell Pathol 21: 183-191.

21. Kayser K, Ogilvie R, Borkenfeld S, Kayser G (2011) E-education in pathology including certification of e-institutions. Diagn Pathol 1: 11.

22. Kayser K, Borkenfeld S, Goldmann T, Kayser G (2011) Virtual slides in peer reviewed, open access medical publication. Diagn Pathol 6: 124. 